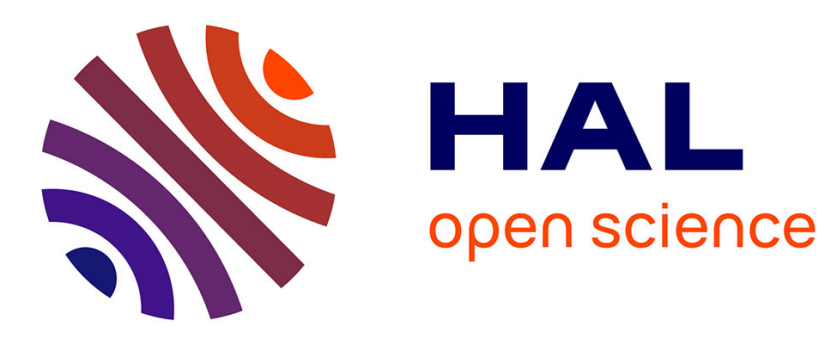

\title{
A neutron diffraction study of the oxygen diffusion in molybdenum doped Ba2InO5
}

Aurélie Rolle, Pascal Roussel, Nambi-V Giridharan, Emmanuelle Suard, Rose-Noëlle Vannier

\section{- To cite this version:}

Aurélie Rolle, Pascal Roussel, Nambi-V Giridharan, Emmanuelle Suard, Rose-Noëlle Vannier. A neutron diffraction study of the oxygen diffusion in molybdenum doped Ba2InO5. Solid State Ionics, 2007, soumis, pp.xx-xx. hal-00187450

\section{HAL Id: hal-00187450 \\ https://hal.science/hal-00187450}

Submitted on 14 Nov 2007

HAL is a multi-disciplinary open access archive for the deposit and dissemination of scientific research documents, whether they are published or not. The documents may come from teaching and research institutions in France or abroad, or from public or private research centers.
L'archive ouverte pluridisciplinaire HAL, est destinée au dépôt et à la diffusion de documents scientifiques de niveau recherche, publiés ou non, émanant des établissements d'enseignement et de recherche français ou étrangers, des laboratoires publics ou privés. 


\title{
${ }^{*}$ Manuscript
}

1

2

3

4

5

6

7

8

9

10

11

12

13

14

15

\section{A neutron diffraction study of the oxygen diffusion in molybdenum doped $\mathrm{Ba}_{2} \mathrm{In}_{2} \mathrm{O}_{5}$}

\author{
Aurélie Rolle $^{a^{*}}$, Pascal Roussel ${ }^{a}$, Nambi Venkatesan Giridharan ${ }^{a}$,
} Emmanuelle Suard ${ }^{b}$, Rose-Noëlle Vannier ${ }^{a}$

${ }^{a}$ Equipe de Chimie du Solide - UCCS - Unité de Catalyse et Chimie du Solide - UMR 8181 USTL-ENSCL, BP 90 108, 59652 Villeneuve d'Ascq Cedex, France

${ }^{b}$ Institut Laue Langevin, Avenue des martyrs, BP 156, 38042 Grenoble Cedex 9, France

\footnotetext{
* Corresponding author
}

Dr. A. Rolle

Equipe de Chimie du Solide, UCCS - Unité de Catalyse et Chimie du Solide

CNRS UMR 8181, USTL-ENSCL, BP 90 108, 59652 Villeneuve d'Ascq Cedex, France Tel: +33 (0) 320434973

Fax: +33(0) 320436814

E-mail: Aurelie.Rolle@ensc-lille.fr 


\begin{abstract}
The structures of molybdenum doped $\mathrm{Ba}_{2} \mathrm{In}_{2} \mathrm{O}_{5}$ were refined using X-ray and neutron diffraction data at room and high temperature with the aim to derive preferred oxygen diffusion pathways. At room temperature, refinement of composition $\mathrm{Ba}_{2} \mathrm{In}_{2-\mathrm{x}} \mathrm{Mo}_{\mathrm{x}} \mathrm{O}_{5+3 \mathrm{x} / 2}$ with $\mathrm{x}=0.1$ revealed molybdenum atoms are preferentially located in the tetrahedral layers of the brownmillerite. At $700^{\circ} \mathrm{C}$, the structure can be viewed as the stacking of alternating In and In/Mo octahedral layers. The conduction process occurs preferentially in the later which is highly oxygen deficient. Preferred oxygen diffusion pathways were deduced from Joint Probability Density Function (JPDF) and energy barriers were derived. It was in good agreement with the activation energy deduced from impedance spectroscopy for composition $\mathrm{x}=0.1$ at $950^{\circ} \mathrm{C}$. However, calculation of energy barrier assumes a dynamic disorder of oxide ions which is unlikely to occur at lower temperature and for sample containing a larger amount of molybdenum. Composition $\mathrm{x}=0.5$ is cubic on the whole range of temperature. At room temperature, JPDF revealed a static disorder of the oxygen atoms, which is likely due to the solution of molybdenum into the barium indium perovskite. When temperature increases the disorder becomes more and more dynamic.
\end{abstract}

\title{
Keywords
}

Barium oxide, indium oxide, brownmillerite, oxide ion conductor, neutron diffraction, X-ray diffraction, anharmonic model 


\section{Introduction}

In 1990, Goodenough et al. evidenced high oxide ion conduction properties in the high temperature forms of the $\mathrm{Ba}_{2} \operatorname{In}_{2} \mathrm{O}_{5}$ [1]. Since then, numerous substitutions for the indium site or for the barium site have been made to stabilise these conductive forms at lower temperature.

At room temperature, the structure of $\mathrm{Ba}_{2} \mathrm{In}_{2} \mathrm{O}_{5}$ is similar to that of the brownmillerite which can be described as a defective perovskite. Its symmetry is orthorhombic with the

following unit-cell: $a_{B}=\sqrt{2} a_{P}=6.0991 \AA, \quad b_{B}=4 a_{P}=16.7365 \AA, \quad c_{B}=\sqrt{2} a_{P}=5.9622 \AA \quad\left(a_{P}, \quad b_{P}, c_{P}\right.$ corresponding to the perovskite cell) [2]. It can be viewed as an intergrowth of $\operatorname{In}(1) \mathrm{O}_{6}$ octahedral layers alternating with $\operatorname{In}(2) \mathrm{O}_{4}$ tetrahedral layers, barium atoms being located in the $\mathrm{B}$ site of the perovskite. This orthorhombic form changes to a tetragonal polymorph at $\mathrm{T}_{\mathrm{d}} \approx 925^{\circ} \mathrm{C}$. As the temperature increases, the oxygen disorder increases. For temperatures higher than $1040^{\circ} \mathrm{C}$, $\mathrm{Ba}_{2} \mathrm{In}_{2} \mathrm{O}_{5}$ transforms to an oxygen deficient perovskite with cubic symmetry which can be described in the $\mathrm{P} m \overline{3} m$ space group. These two high temperature (tetragonal and cubic) forms are pure oxide ion conductors [3-9] and were tentatively stabilised at room temperature by partial substitution for barium and/or indium. Our group investigated the partial substitution for indium with high valence state metals. Tin, vanadium, niobium, tantalum, molybdenum and tungsten were considered. Solid solutions were evidenced for all the tested metals $[10,11]$. In the case of molybdenum, a $\mathrm{Ba}_{2} \mathrm{In}_{2-\mathrm{x}} \mathrm{Mo}_{\mathrm{x}} \mathrm{O}_{5+3 \mathrm{x} / 2}$ solid solution was obtained for $0 \leq \mathrm{x} \leq 2 / 3$, up to the complete filling of the oxygen vacancies of the perovskite. Cubic forms were stabilised at room temperature for composition with $\mathrm{x} \geq 0.2$. For the orthorhombic polymorph obtained with lower $\mathrm{x}$ value, impedance spectroscopy and high temperature X-ray diffraction revealed a decrease of the order-disorder transition temperature with the increase of the substitution level. But the fast oxide ion conductivity decreased with the increase of the substitution rate. Composition $\mathrm{x}=0.1$ is orthorhombic at room temperature, it transforms to a tetragonal form at $600^{\circ} \mathrm{C}$ and its symmetry becomes cubic at $925^{\circ} \mathrm{C}$. The Arrhenius plot, $\log (\sigma \mathrm{T})=\mathrm{A} \exp (-\mathrm{Ea} / \mathrm{kT})$, derived from the data reported in [10], is given in Fig. 1. The transition from the tetragonal form to the cubic form is not clearly visible. In the case of composition $x=0.1$, an activation energy of $1 \mathrm{eV}$ was deduced at temperature higher than $600^{\circ} \mathrm{C}$. It was $0.8 \mathrm{eV}$ for composition $\mathrm{x}=0.5$ for temperature higher than $600^{\circ} \mathrm{C}$. 


\section{Experimental}

$\mathrm{Ba}_{2} \operatorname{In}_{2-\mathrm{x}} \mathrm{Mo}_{\mathrm{x}} \mathrm{O}_{5+3 / 2 \mathrm{x}} \mathrm{x}=0.1$ and $\mathrm{x}=0.5$ compositions were prepared by classical solid-state route from stoichiometric mixtures of $\mathrm{In}_{2} \mathrm{O}_{3}$ (Aldrich, 99.99\%), $\mathrm{BaCO}_{3}$ (Aldrich 99\%), $\mathrm{MoO}_{3}$ (Prolabo, 99-100\%) reagents at $1000^{\circ} \mathrm{C}, 1200^{\circ} \mathrm{C}$ and $1300^{\circ} \mathrm{C}$ with intermediate grindings [10]. Powders were dried at $500^{\circ} \mathrm{C}$ for 1 hour (heating rate: $10^{\circ} \mathrm{C} / \mathrm{min}$, cooling rate: $20^{\circ} \mathrm{C} / \mathrm{min}$ ) under a flow of dried air to avoid any traces of hydrates before the data collection. Both compositions were checked by EDX analysis before further characterisations. The experiments were performed on a Jeol 5300 scanning electron microscope equipped with a Princeton Gamma Technology energy dispersive detector. $\mathrm{Ba}_{2} \mathrm{In}_{2} \mathrm{O}_{5}$ and $\mathrm{MoO}_{3}$ were used as references. It led to the following compositions: $\mathrm{Ba}_{2} \mathrm{In}_{1.90} \mathrm{Mo}_{0.10} \mathrm{O}_{5.15}$ and $\mathrm{Ba}_{2} \mathrm{In}_{1.49} \mathrm{Mo}_{0.51} \mathrm{O}_{5.76}$ in very close agreement with the starting compositions and confirmed there had been no volatilisation of molybdenum.

Neutron diffraction data were collected at room temperature on the high resolution powder diffractometer D2B at the Institut Laue Langevin (I.L.L.) at Grenoble. To perform collection under air atmosphere, approximately $20 \mathrm{~g}$ of powder were introduced in a quartz tube, which was open at one end. This tube was introduced in the furnace and data were collected in the $0.3-160^{\circ}$ range with a step of $0.05^{\circ}$. Collection was performed at room temperature, $700^{\circ} \mathrm{C}$ and $950^{\circ} \mathrm{C}$ for composition $\mathrm{x}=0.1$ and room temperature and $750^{\circ} \mathrm{C}$ for composition $\mathrm{x}=0.5$. 


\section{Results and discussions}

\subsection{Composition $x=0.1$ at room temperature}

The orthorhombic symmetry of composition $\mathrm{x}=0.1$ was confirmed by X-ray diffraction. However, because of the close atomic numbers of $\operatorname{In}(Z=49)$ and Mo $(Z=42)$, it was not possible to define clearly in which site the substituting metal was located using X-ray data only. A better separation was expected with neutron diffraction, Fermi lengths being $4.06 \mathrm{fm}$ and $6.9 \mathrm{fm}$ for indium and molybdenum, respectively. The wavelength of neutron being not accurate, it was refined with the unit cell parameters of this composition constrained to the value obtained from X-ray diffraction data. This led to a value of $\lambda=1.59483(2) \AA$.

To describe the brownmillerite type structure, several structural models were reported in the literature. $\mathrm{Ca}_{2} \mathrm{Fe}_{2} \mathrm{O}_{5}$ was described in Pcmn [15] and $\mathrm{Ba}_{2} \mathrm{In}_{2} \mathrm{O}_{5}$ in Ibm2 [14] and Icmm [2] space groups. The structural models in Ibm2 and Pcmn differ from the orientation of the $\operatorname{In}(2) \mathrm{O}_{4}$ tetrahedra (Fig. 2) in the oxygen deficient layers and, as shown by Berastegui using TEM [2], the reality is likely a mixture of these different configurations. Therefore, the structure is better described in the Icmm which can be considered as the superimposition of these two later models. 


\subsection{Composition $x=0.1$ at $700^{\circ} \mathrm{C}$}

At $700^{\circ} \mathrm{C}$, X-ray diffraction confirmed the tetragonal symmetry of this composition. The structure of the tetragonal polymorph of $\mathrm{Ba}_{2} \mathrm{In}_{2} \mathrm{O}_{5}$ was tentatively described by Speakman et al. in the following unit cell $\mathrm{a}_{\mathrm{T}}=\mathrm{b}_{\mathrm{T}}=\mathrm{a}_{\mathrm{B}}=\sqrt{2} \mathrm{a}_{\mathrm{P}}$ and $\mathrm{c}_{\mathrm{T}}=\mathrm{b}_{\mathrm{B}}=4 \mathrm{a}_{\mathrm{P}}$ [9]. They obtained the best agreement factors in the $14 \mathrm{~cm}$ space group. However, a rapid analysis of the coordinates of atoms revealed some correlations between positions and questioned the quadrupling of the stacking parameters. 
In fact, the structure of $\mathrm{Ba}_{2} \mathrm{In}_{2} \mathrm{O}_{5}$ derivatives with a tetragonal symmetry was described by numerous authors in a double perovskite with $\mathrm{c}_{\mathrm{T}}=2 \mathrm{a}_{\mathrm{P}}[14,16-19]$. The double perovskite was also confirmed by TEM by Jayaraman et al. [20], Liu et al. [21] and Kambe et al. [22] for $\mathrm{Ba}_{2}\left(\mathrm{In}_{1-}\right.$ $\left.{ }_{\mathrm{x}} \mathrm{Ti}_{\mathrm{x}}\right)_{2} \mathrm{O}_{5},\left(\mathrm{Ba}_{1-\mathrm{x}} \mathrm{La}_{\mathrm{x}}\right)_{2} \mathrm{In}_{2} \mathrm{O}_{5+\mathrm{x}}$ and $\mathrm{Ba}_{2} \mathrm{InCuO}_{4.53}$, respectively. In their paper, Speakman et al. gave no evidence of a quadrupling of the perovskite unit-cell along the [001] direction and the high temperature tetragonal form of $\mathrm{Ba}_{2} \mathrm{In}_{2} \mathrm{O}_{5}$ is likely a double perovskite composed of two octahedral layers, one being oxygen defective.

Neutron diffraction data were therefore refined in the $P 4 / \mathrm{mmm}$ space group, assuming a double perovskite unit-cell. The wavelength of the neutron being known from the experiment performed at room temperature, unit cell parameters were refined. It led to parameters very close to those derived from X-ray diffraction (Table 2). No extra Bragg peaks was observed, either on the X-ray patterns, or on the neutron patterns. Due to the fast oxygen motion, a large disorder of oxide ions was noticed in the oxygen deficient layers. To take into account all the nuclear density of $\mathrm{O}(2)$ and $\mathrm{O}(3)$ oxygen atoms, an anharmonic description of the thermal parameters at the $4^{\text {th }}$ order was used. The Hamilton test [23] was carried out to compare the anharmonic description (27 refined parameters, 92 reflexions) to the model with an anisotropic description of the thermal motion of oxygen atoms (15 refined parameters, 92 reflexions). This led to the following reliability factor for the anharmonic model: Robs: 2.55 , Rwobs: 1.39 , compared to Robs: 4.04 , Rwpbs: 2.33 for the anisotropic model. Statistical calculations revealed that the anharmonic description is better than the anisotropic description with a 995/1000 probability. In contrast, thermal displacement of barium, indium, molybdenum and oxygen $\mathrm{O}(1)$ atoms could be fitted using classical anisotropic parameters. Refinement of the molybdenum occupancy in both indium sites confirmed it was located in the $\operatorname{In}(2)$ site. Refinement of the oxygen atoms occupancy revealed the apical $\mathrm{O}(2)$ site was fully occupied and oxygen vacancies were spread on the two $\mathrm{O}(1)$ and $\mathrm{O}(3)$ equatorial sites. The model deduced from neutron diffraction was used to refine $\mathrm{X}$ ray diffraction data collected on the same composition, at the same temperature. As previously, oxygen positions were maintained at the positions derived from neutron diffraction and only the positions of heavy atoms were refined in this case. Close values were derived. The results of both refinements are given in Table 2 and calculated data are compared to experimental data in Fig. 5. A drawing of the Joint Probability Density Function (JPDF) of oxygen nucleons around the indium atoms is given in Fig. 6. It represents the probability to find an oxygen atom around its 
equilibrium position. A large disorder of the oxygen nuclear density is clearly observed around the $\operatorname{In}(2)$ site, in contrast to the $\operatorname{In}(1)$ site. Oxygen vacancies are also mainly located in the $\operatorname{In}(2)$ layers, although a few vacancies are observed in the $\operatorname{In}(1)$ layers. The presence of oxygen vacancies in the $\operatorname{In}(1)$ layers is not surprising. Indeed, calculation of defect energy in the parent compound, $\mathrm{Ba}_{2} \mathrm{In}_{2} \mathrm{O}_{5}$, led to the conclusion that formation of Frenkel defect involving an oxygen vacancy in the octahedral layers associated to an interstitial oxide in the tetrahedral layers of $\mathrm{Ba}_{2} \mathrm{In}_{2} \mathrm{O}_{5}$ was most favourable [24]. The increase of their concentration would explain the sudden increase in conductivity observed for the parent compound at temperature higher than $925^{\circ} \mathrm{C}$ and the transformation to the perovskite at $1040^{\circ} \mathrm{C}$.

To derive preferential oxygen diffusion pathways in the molybdenum doped materials, pseudo-potentials were calculated. Indeed the vibration of an atom around its equilibrium position depends on the interactions bringing it back to its equilibrium position and these interactions can be described by pseudo-potentials related to the probability of a given path [25]. From JPDF, pseudo-potential can be calculated and allow to define preferred oxygen diffusion pathways. These calculations were already applied to BIMEVOX compounds [26-27]. For data collected on the parent compound, $\mathrm{Bi}_{4} \mathrm{~V}_{2} \mathrm{O}_{11}$, at $700^{\circ} \mathrm{C}$, an energy barrier of $0.16 \mathrm{eV}$ was derived. It was in good agreement with the experimental value measured by impedance spectroscopy. In the present study, from the previous JPDF, numerous pathways were considered and the lowest energy barriers were observed for the jump of an equatorial $\mathrm{O}(3)$ oxide to a consecutive equatorial $\mathrm{O}(3)$ oxide in the $\operatorname{In}(2)$ layers with a value of $0.4 \mathrm{eV}$. A value of $0.6 \mathrm{eV}$ was deduced for the jump of an apical site to an equatorial site in the same layers. Since oxygen vacancies were also evidenced in the In(1) layers, one could expect the possibility of oxygen motion in these layers. The lowest energy barrier in these $\operatorname{In}(1)$ layers was deduced for the jump of an apical O(1) site to an adjacent apical $\mathrm{O}(1)$ site with a barrier of $3.9 \mathrm{eV}$. Jumps from an equatorial site to an apical site in the same layers were also considered but appeared to be not possible. In summary, the most probable pathway for oxygen ions (i.e. having the lowest potential) is in the $\operatorname{In}(2)$ layers from an equatorial to an equatorial site with an activation energy of $0.4 \mathrm{eV}$. And therefore, an activation energy of $0.4 \mathrm{eV}$ would be expected for the present composition at $700^{\circ} \mathrm{C}$. However, a value of $1 \mathrm{eV}$ was derived from impedance spectroscopy. In fact, these pseudo-potentials have to be used with care. They only give qualitative information on the possibility of oxide migration and suppose a dynamic disorder of atoms. Indeed, one can not exclude the possibility that the nuclear density 

superimposition of different oxygen surrounding of indium atoms instead of a dynamic disorder. This is even more likely that $700^{\circ} \mathrm{C}$ is very close to the transition of phase from the orthorhombic to the tetragonal form.

\subsection{Composition $x=0.1$ at $950^{\circ} \mathrm{C}$}

At $950^{\circ} \mathrm{C}$, both $\mathrm{X}$-ray and neutron diffraction revealed a cubic symmetry. The structure was refined in the $P m \overline{3} \mathrm{~m}$ space group using the model of the perovskite. Isotropic displacement parameters were used to describe the thermal motions of barium, indium, and molybdenum atoms. In contrast, an anharmonic tensor of the $4^{\text {th }}$ order was used for oxygen atoms. Results of the refinement of X-ray and neutron data are given in Table 3 and calculated data are compared to experimental data in Fig. 7. The model was confirmed using data collected at $\lambda \sim 1.05 \AA$. Only data collected at $\lambda \sim 1.6 \AA$ are presented here since the D2B diffractometer is optimized for $\lambda \sim 1.6$ $\AA$ and consequently the resolution is better for this wavelength. The three dimensions plot of the JPDF of oxygen nucleon is reported in Fig. 8. When considering the jump of an oxygen atom to an adjacent one, an energy barrier of $1.1 \mathrm{eV}$ was deduced in agreement with the experimental value of $1 \mathrm{eV}$ obtained by impedance spectroscopy in the domain of temperature. The disorder observed at this temperature is likely dynamic which allows the comparison in this case [25].

\subsection{Composition $x=0.5$ at room temperature and at $750^{\circ} \mathrm{C}$}

For composition $\mathrm{x}=0.5$, a cubic form was stabilized at room temperature. Data were collected at room temperature and at $750^{\circ} \mathrm{C}$. The refinements of neutron diffraction data only are reported. Since the wavelength of neutron had been changed between two measurements, it was refined again with the unit cell parameters constrained to the values obtained from X-ray diffraction at room temperature. This led to a value of $\lambda=1.59599(3) \AA$. Then, the model of the cubic perovskite was introduced. Isotropic displacement parameters were used to describe the thermal motions of barium, indium, molybdenum, and anharmonic tensors of the $4^{\text {th }}$ order to describe those of oxygen atoms. Results of the refinements are given in Table 4 and 5. The 3D plot of the JPDF for oxygen nucleon at room temperature is compared to JPDF for oxygen nucleon at $750^{\circ} \mathrm{C}$ in Fig. 11 . At $750^{\circ} \mathrm{C}$, it is similar to the JPDF observed at $950^{\circ} \mathrm{C}$ for $\mathrm{x}=0.1$. At room temperature, the nucleon density of oxide ions is split. These shapes are unlikely due to 
thermal motion, but are more probably the result of the superimposition of different local environments around the molybdenum and indium atoms with two different bond lengths equal to $1.88 \AA$ and $2.29 \AA$. An EXAFS study at the $\mathrm{L}_{\mathrm{III}}$ edge of tungsten and $\mathrm{L}_{\mathrm{I}}$ edge of indium in tungsten doped derivatives revealed for cubic forms two different In-O bond lengths in good proportion with the tungsten amount indicating different oxygen surrounding for indium atoms whether it is close to a tungsten atom or not [28]. No superlattice reflection was revealed by TEM, indicating a perfect solution of tungsten in the structure. This scenario is likely the same for Mo-doped compounds.

\section{Conclusions}

To derive preferred oxygen diffusion pathways, the structures of molybdenum doped $\mathrm{Ba}_{2} \mathrm{In}_{2} \mathrm{O}_{5}$ were refined from X-ray and neutron diffraction data at room and high temperature. At room temperature, refinement of composition $\mathrm{Ba}_{2} \operatorname{In}_{2-\mathrm{x}} \mathrm{Mo}_{\mathrm{x}} \mathrm{O}_{5+3 \mathrm{x} / 2}$ with $\mathrm{x}=0.1$ revealed molybdenum atoms to be preferentially located in the tetrahedral layers of $\mathrm{Ba}_{2} \operatorname{In}_{2} \mathrm{O}_{5}$. At $700^{\circ} \mathrm{C}$, the structure can be viewed as the stacking of alternating In and In/Mo octahedral layers. The conduction process occurs preferentially in the later which is highly oxygen deficient. Preferred oxygen pathways were deduced from Joint Probability Density Function (JPDF) and energy barriers were derived. It was in good agreement with the activation energy deduced from impedance spectroscopy for composition $\mathrm{x}=0.1$ at $950^{\circ} \mathrm{C}$. However, calculation of energy barrier assumes a dynamic disorder of oxide ion which is unlikely at lower temperature and for sample containing a larger amount of molybdenum. Composition $\mathrm{x}=0.5$ is cubic on the whole range of temperature. At room temperature, JPDF revealed a static disorder of the oxygen atoms likely due to the solution of molybdenum into the barium indium perovskite. When temperature increases the disorder becomes more and more dynamic. 


\section{Acknowledgements}

The Institut Laue Langevin is thanked for providing neutron facilities. The authors are also very grateful to L. Burylo and N. Djelal for help with the X-ray diffraction and EDX analysis. The Fonds Européen de Développement Régional (FEDER), the Centre National de la Recherche Scientifique (CNRS), the Région Nord Pas-de-Calais and the Ministère de l'Education Nationale, de l'Enseignement Supérieur et de la Recherche are acknowledged for funding of Xray diffractometers. Aurelie Rolle is also very grateful to the CNRS and the Région Nord Pas-deCalais for funding her $\mathrm{PhD}$.

\section{References}

[1] J. B Goodenough, J. E Ruiz-Diaz, Y.S. Zhen, Solid State Ionics 44 (1990) 21.

[2] P. Berastegui, S. Hull, F.J. García-García, S.G. Eriksson, J. Solid State Chem. 164 (2002) 119.

[3] T.R.S. Prasanna, A. Navrotsky, J. Mater. Res. 8 (1993) 1484.

[4] S. B. Adler, J.A. Reimer, J. Baltisberger, U. Werner, J. Am. Chem. Soc. 116 (1994) 675.

[5] G. B. Zhang, D. M. Smyth, Solid State Ionics 82 (1995) 161.

[6] M. Kanzaki, A. Yamaji, Mater. Sci Eng. B41 (1996) 46.

[7] T. Hashimoto, Y.Ueda, M. Yoshinaga, K. Komazaki, K. Asaoka, S. Wang, J. Electrochem. Soc. 149 (2002) 1381.

[8] T. Hashimoto, K. Asaoka, K. Komazaki, Y. Ueda Y, M. Yoshinaga, Electrochemical Society Proceedings 28 (2001) 291.

[9] S.A. Speakman, J.W. Richardson, B.J. Mitchell, S.T. Misture, Solid State Ionics 149 (2002) 247.

[10] A. Rolle, N.V. Giridharan, R.N. Vannier, F. Abraham, Solid State Ionics 176 (2005) 2095. 
[11] A. Rolle, N.V. Giridharan, P. Roussel, F. Abraham, R.N. Vannier, MRS Symposium Proceedings (2005) 835, K.2.4.1.

[12] V. Petricek, M. Dusek, The crystallographic computing system JANA 2000; Institute of Physics: Praha, Czech Republic, 2006.

[13] Eck B., wxDragon; Institut für Anorganische Chemie der RWTH: Aachen, Germany, 2006.

[14] D.H. Gregory, M.T.Weller, J. Solid State Chem.107 (1993) 134.

[15] C. Greaves, A.J. Jacobson, B.C. Tofield, B.E.F. Fender, Acta Crystallogr. Sect B31 (1975) 641.

[16] C. Tenailleau, A. Pring, S.M. Moussa, Y. Liu, R.L. Withers, S. Tarantino, M. Zhang, A. Carpenter, J. Solid State Chem. 178 (2005) 882.

[17] A.L. Kharlanov, Russian J. Inorg. Chem. 35(12) (1990) 1741.

[18] G. Kallias, M. Pissas, A. Simopoulos, D. Niarchos, Mater. Res. Bull. 32(6) (1997) 791.

[19] A.K. Ganguli , T.N. Guru Row, Mater. Res. Bull. 29(12) 19941333.

[20] V. Jayaraman , A. Magrez, M. Caldes, O. Joubert, M. Ganne, Y. Piffard, L. Brohan, Solid State Ionics 170 (2004) 17.

[21] Y. Liu, R.L. Withers, J.F. Gerald, J. Solid State Chem.170 (2003) 247.

[22] S. Kambe, I. Shime, S. Ohshima, K. Okuyama, N. Ohnishi, K. Hiraga, Physica C220 (1994) 119.

[23] W.C. Hamilton, Acta Cryst.18 (1965) 502.

[24] A. Rolle, C.A.J. Fisher, R.N. Vannier, M.S. Islam, to be submitted.

[25] R. Bachman, H. Schulz, Acta Crystallogr. Sect. A 40 (1984) 668.

[26] P. Roussel, R.N. Vannier, M. Anne, G. Nowogrocki, G. Mairesse, Acta Crystallogr. Sect. A 58 (2002) C319.

[27] P. Roussel, R.N. Vannier, M. Anne, G. Nowogrocki, G. Mairesse, to be submitted. 
[28] S. Daviero-Minaud, A. Rolle, C. Kongmark, R.N. Vannier, "X-ray absorption study of $\mathrm{Ba}_{2} \mathrm{In}_{2-\mathrm{x}} \mathrm{W}_{\mathrm{x}} \mathrm{O}_{5+3 \mathrm{x} / 2}$ compounds", to be submitted.

\section{Table captions}

Table 1. Structural model of $\mathrm{Ba}_{2} \operatorname{In}_{2-\mathrm{x}} \mathrm{Mo}_{\mathrm{x}} \mathrm{O}_{5+3 \mathrm{x} / 2}(\mathrm{x}=0.1)$ described in the Icmm space group deduced from the refinement of neutron and X-ray diffraction data collected at room temperature $(\lambda=1.59483(2) \AA)$

Table 2. Structural model of $\mathrm{Ba}_{2} \mathrm{In}_{2-\mathrm{x}} \mathrm{Mo}_{\mathrm{x}} \mathrm{O}_{5+3 \mathrm{x} / 2}(\mathrm{x}=0.1)$ described in the $P 4 / \mathrm{mmm}$ space group deduced from the refinement of neutron and X-ray diffraction data collected at $700^{\circ} \mathrm{C}$ $(\lambda=1.59483(2) \AA)$

Table 3. Structural model of $\mathrm{Ba}_{2} \mathrm{In}_{2-\mathrm{x}} \mathrm{Mo}_{\mathrm{x}} \mathrm{O}_{5+3 \mathrm{x} / 2}(\mathrm{x}=0.1)$ described in the $P m \overline{3} m$ space group deduced from the refinement of neutron and X-ray diffraction data collected at $950^{\circ} \mathrm{C}$ $(\lambda=1.59483(2) \AA)$

Table 4. Structural model of $\mathrm{Ba}_{2} \mathrm{In}_{2-\mathrm{x}} \mathrm{Mo}_{\mathrm{x}} \mathrm{O}_{5+3 \mathrm{x} / 2}(\mathrm{x}=0.5)$ described in the $P m \overline{3} m$ space group deduced from the refinement of neutron and X-ray diffraction data collected at room temperature $(\lambda=1.59599(3) \AA)$

Table 5. Structural model of $\mathrm{Ba}_{2} \mathrm{In}_{2-\mathrm{x}} \mathrm{Mo}_{\mathrm{x}} \mathrm{O}_{5+3 \mathrm{x} / 2}(\mathrm{x}=0.5)$ described in the $P m \overline{3} m$ space group deduced from the refinement of neutron data collected at $750^{\circ} \mathrm{C}(\lambda=1.59599(3) \AA)$ 


\section{Tables}

Table 1

Structural model of $\mathrm{Ba}_{2} \mathrm{In}_{2-\mathrm{x}} \mathrm{Mo}_{\mathrm{x}} \mathrm{O}_{5+3 \mathrm{x} / 2}(\mathrm{x}=0.1)$ described in the Icmm space group deduced from the refinement of neutron and X-ray diffraction data collected at room temperature $(\lambda=1.59483(2) \AA)$

\begin{tabular}{cccccc}
\hline$\underline{\text { Icmm }}$ & $\mathrm{a}(\AA)$ & $\mathrm{b}(\AA)$ & $\mathrm{c}(\AA)$ & volume $\left(\AA^{3}\right)$ & density \\
\hline & $6.0293(6)$ & $16.822(2)$ & $5.9616(6)$ & $604.7(2)$ & $6.5(1)$ \\
\hline
\end{tabular}

\begin{tabular}{cccccccc}
\hline atom & Site & diffraction & $\mathrm{X}$ & $\mathrm{y}$ & $\mathrm{z}$ & occupancy & $\mathrm{U}_{\text {iso }}\left(\AA^{2}\right)$ \\
\hline $\mathrm{Ba}$ & $8(\mathrm{~h})$ & neutron & $0.508(1)$ & $0.6111(2)$ & 0 & 1 & $0.0112(9)$ \\
& & X-ray & $0.5058(9)$ & $0.612(1)$ & 0 & 1 & $0.005(1)$ \\
\hline $\mathrm{In}(1)$ & $4(\mathrm{a})$ & neutron & 0 & 0 & 0 & 1 & $0.005(1)$ \\
& & X-ray & 0 & 0 & 0 & 1 & $0.003(2)$ \\
\hline $\mathrm{In}(2) / \mathrm{Mo}(2)$ & $8(\mathrm{i})$ & neutron & $0.547(2)$ & 0.25 & $0.477(6)$ & $0.45 / 0.05$ & $0.026(4)$ \\
& & X-ray & $0.541(1)$ & 0.25 & $0.480(6)$ & $0.45 / 0.05$ & $0.014(3)$ \\
\hline $\mathrm{O}(1)$ & $8(\mathrm{~g})$ & neutron & 0.25 & $0.9957(4)$ & 0.25 & $0.995(6)$ & $0.0147(8)$ \\
& & X-ray & 0.25 & 0.9957 & 0.25 & 0.995 & 0.0147 \\
\hline $\mathrm{O}(2)$ & $8(\mathrm{~h})$ & neutron & $0.037(1)$ & $0.1360(3)$ & 0 & 1 & $0.038(1)$ \\
& & X-ray & 0.037 & 0.1360 & 0 & 1 & 0.038 \\
\hline $\mathrm{O}(3)$ & $8(\mathrm{i})$ & neutron & $0.649(2)$ & 0.25 & $0.152(2)$ & $0.483(4)$ & $0.031(3)$ \\
& & X-ray & 0.649 & 0.25 & 0.152 & 0.483 & 0.031 \\
\hline $\mathrm{O}(4)$ & $4(\mathrm{c})$ & neutron & 0.25 & 0.25 & 0.25 & $0.194(4)$ & $0.05(1)$ \\
& & X-ray & 0.25 & 0.25 & 0.25 & 0.194 & 0.05 \\
& & & & & & 05 \\
\hline
\end{tabular}


Table 2

Structural model of $\mathrm{Ba}_{2} \mathrm{In}_{2-\mathrm{x}} \mathrm{Mo}_{\mathrm{x}} \mathrm{O}_{5+3 \mathrm{x} / 2}(\mathrm{x}=0.1)$ described in the P4/mmm space group deduced from the refinement of neutron and X-ray diffraction data collected at $700^{\circ} \mathrm{C}(\lambda=1.59483(2) \AA)$

\begin{tabular}{|c|c|c|c|c|c|c|c|}
\hline P4/mmm & $\mathrm{a}(\AA)$ & \multicolumn{2}{|l|}{$\mathrm{b}(\AA)$} & $\mathrm{c}(\AA)$ & volume $\left(\AA^{3}\right)$ & \multicolumn{2}{|c|}{ density } \\
\hline neutrons & $4.2589(3)$ & \multicolumn{2}{|c|}{$4.2589(3)$} & $8.5234(5)$ & $154.60(1)$ & \multicolumn{2}{|c|}{$6.2797(3)$} \\
\hline $\mathrm{X}$ rays & $4.2589(3)$ & \multicolumn{2}{|c|}{$4.2589(3)$} & $8.5202(2)$ & $154.54(2)$ & \multicolumn{2}{|c|}{$6.2820(8)$} \\
\hline atom & site & diffraction & $\mathrm{X}$ & $\mathrm{y}$ & $\mathrm{Z}$ & occupancy & $\mathrm{U}_{\text {eq }}\left(\AA^{2}\right)$ \\
\hline \multirow[t]{2}{*}{$\mathrm{Ba}$} & \multirow[t]{2}{*}{$2(\mathrm{~h})$} & neutrons & 0.5 & 0.5 & $0.2348(6)$ & 1 & $0.050(2)$ \\
\hline & & $\mathrm{X}$ rays & 0.5 & 0.5 & $0.230(1)$ & 1 & $0.016(8)$ \\
\hline \multirow[t]{2}{*}{$\operatorname{In}(1)$} & \multirow[t]{2}{*}{ (1a) } & \multirow{2}{*}{$\begin{array}{c}\text { neutrons } \\
\text { X rays }\end{array}$} & 0 & 0 & 0 & 1 & $0.03(6)^{*}$ \\
\hline & & & 0 & 0 & 0 & 1 & $0.02(2)^{*}$ \\
\hline \multirow[t]{2}{*}{$\operatorname{In}(2) / \operatorname{Mo}(2)$} & \multirow[t]{2}{*}{ (1b) } & neutrons & 0 & 0 & 0.5 & $0.9 / 0.1$ & $0.089(5)^{*}$ \\
\hline & & $\mathrm{X}$ rays & 0 & 0 & 0.5 & $0.9 / 0.1$ & $0.04(3)^{*}$ \\
\hline \multirow[t]{2}{*}{$\mathrm{O}(1)$} & \multirow[t]{2}{*}{$(2 f)$} & \multirow{2}{*}{$\begin{array}{c}\text { neutrons } \\
X \text { rays }\end{array}$} & 0.5 & 0 & 0 & $0.935(7)$ & $0.056(3)^{*}$ \\
\hline & & & 0.5 & 0 & 0 & 0.935 & $0.056^{*}$ \\
\hline \multirow[t]{2}{*}{$\mathrm{O}(2)$} & \multirow[t]{2}{*}{$(2 g)$} & \multirow{2}{*}{$\begin{array}{c}\text { neutrons } \\
\text { X rays }\end{array}$} & 0 & 0 & $0.268(1)$ & 1 & $0.179(8)^{*}$ \\
\hline & & & 0 & 0 & 0.268 & 1 & $0.179^{* *}$ \\
\hline \multirow[t]{2}{*}{$\mathrm{O}(3)$} & \multirow[t]{2}{*}{$(2 \mathrm{e})$} & \multirow{2}{*}{$\begin{array}{c}\text { neutrons } \\
\text { X rays }\end{array}$} & 0.5 & 0 & 0.5 & $0.640(4)$ & $0.53(5)^{* *}$ \\
\hline & & & 0.5 & 0 & 0.5 & 0.640 & $0.53^{* *}$ \\
\hline
\end{tabular}

\begin{tabular}{cccccccc}
\hline${ }^{*} \mathrm{U}_{\text {aniso }}$ & & $\mathrm{U}_{11}$ & $\mathrm{U}_{22}$ & $\mathrm{U}_{33}$ & $\mathrm{U}_{12}$ & $\mathrm{U}_{13}$ & $\mathrm{U}_{23}$ \\
\hline $\mathrm{Ba}$ & neutrons & $0.07(3)$ & $0.07(3)$ & $0.006(3)$ & 0 & 0 & 0 \\
& X rays & $0.02(1)$ & $0.02(1)$ & $0.01(2)$ & 0 & 0 & 0 \\
\hline $\mathrm{In}(1)$ & neutrons & $0.0257(5)$ & $0.0257(5)$ & $0.0520(4)$ & 0 & 0 & 0 \\
& X rays & $0.01(2)$ & $0.01(2)$ & $0.03(5)$ & 0 & 0 & 0 \\
\hline $\mathrm{In}(2)$ & neutrons & $0.14(1)$ & $0.14(1)$ & $0.008(3)$ & 0 & 0 & 0 \\
& X rays & $0.05(2)$ & $0.05(2)$ & $0.02(5)$ & 0 & 0 & 0 \\
\hline $\mathrm{Mo}(2)$ & neutrons & $0.14(1)$ & $0.14(1)$ & $0.008(3)$ & 0 & 0 & 0 \\
& X rays & $0.05(2)$ & $0.05(2)$ & $0.02(5)$ & 0 & 0 & 0 \\
\hline $\mathrm{O}(1)$ & neutrons & $0.042(5)$ & $0.048(5)$ & $0.078(7)$ & 0 & 0 & 0 \\
& X rays & 0.042 & 0.048 & 0.078 & 0 & 0 & 0 \\
\hline
\end{tabular}

\begin{tabular}{cccccccc}
\hline${ }^{* *} \mathrm{U}_{\text {anharm }}$ & & $\mathrm{U}_{11}$ & $\mathrm{U}_{22}$ & $\mathrm{U}_{33}$ & $\mathrm{U}_{12}$ & $\mathrm{U}_{13}$ & $\mathrm{U}_{23}$ \\
\hline $\mathrm{O}(2)$ & neutrons & $0.27(1)$ & $0.27(1)$ & $0.012(5)$ & 0 & 0 & 0 \\
& $\mathrm{X}$ rays & 0.27 & 0.27 & 0.012 & 0 & 0 & 0 \\
\hline $\mathrm{O}(3)$ & neutrons & $0.11(2)$ & $1.4(1)$ & $0.10(2)$ & 0 & 0 & 0 \\
& $\mathrm{X}$ rays & 0.11 & 1.4 & 0.10 & 0 & 0 & 0 \\
\hline
\end{tabular}

* an anisotropic description of the thermal parameter was used

** an anharmonic description of the thermal parameters at the $4^{\text {th }}$ order was used 


\section{Table 3}

Structural model of $\mathrm{Ba}_{2} \operatorname{In}_{2-\mathrm{x}} \mathrm{Mo}_{\mathrm{x}} \mathrm{O}_{5+3 \mathrm{x} / 2}(\mathrm{x}=0.1)$ described in the $P m \overline{3} m$ space group deduced from the refinement of neutron and X-ray diffraction data collected at $950^{\circ} \mathrm{C}(\lambda=1.59483(2) \AA)$

\begin{tabular}{lcccll}
\hline $\boldsymbol{P} \boldsymbol{m} \overline{\mathbf{3}} \boldsymbol{m}$ & $\mathrm{a}(\AA)$ & $\mathrm{b}(\AA)$ & $\mathrm{c}(\AA)$ & volume $\left(\AA^{3}\right)$ & density \\
\hline neutrons & $4.2706(1)$ & $4.2706(1)$ & $4.2706(1)$ & $77.855(2)$ & $6.2324(1)$ \\
X rays & $4.2699(1)$ & $4.2699(1)$ & $4.2699(1)$ & $77.852(3)$ & $6.2350(3)$ \\
\hline
\end{tabular}

\begin{tabular}{cccccccc}
\hline atom & site & diffraction & $\mathrm{X}$ & $\mathrm{y}$ & $\mathrm{z}$ & occupancy & $\mathrm{U}_{\text {iso }}\left(\AA^{2}\right)$ \\
\hline $\mathrm{Ba}$ & $1(\mathrm{~b})$ & neutrons & 0.5 & 0.5 & 0.5 & 1 & $0.055(1)$ \\
& & X rays & 0.5 & 0.5 & 0.5 & 1 & $0.030(6)$ \\
\hline $\mathrm{In} / \mathrm{Mo}$ & (1a) & neutrons & 0 & 0 & 0 & $0.95 / 0.05$ & $0.051(1)$ \\
& & X rays & 0 & 0 & 0 & $0.95 / 0.05$ & $0.030(8)$ \\
\hline $\mathrm{O}(1)$ & $3(\mathrm{f})$ & neutrons & 0 & 0 & 0.5 & 0.86 & $0.10(3)^{* *}$ \\
& & X rays & 0 & 0 & 0.5 & 0.86 & 0.102 \\
\hline
\end{tabular}

\begin{tabular}{ccccccc}
\hline${ }^{* *} \mathrm{U}_{\text {anharm }}$ & $\mathrm{U}_{11}$ & $\mathrm{U}_{22}$ & $\mathrm{U}_{33}$ & $\mathrm{U}_{12}$ & $\mathrm{U}_{13}$ & $\mathrm{U}_{23}$ \\
\hline $\mathrm{O}$ & $0.120(3)$ & $0.120(3)$ & $0.066(3)$ & 0 & 0 & 0 \\
\hline
\end{tabular}


Table 4

Structural model of $\mathrm{Ba}_{2} \mathrm{In}_{2-\mathrm{x}} \mathrm{Mo}_{\mathrm{x}} \mathrm{O}_{5+3 \mathrm{x} / 2}(\mathrm{x}=0.5)$ described in the $P m \overline{3} m$ space group deduced from the refinement of neutron and X-ray diffraction data collected at room temperature $(\lambda=1.59599(3)$

A)

\begin{tabular}{lcccll}
\hline $\boldsymbol{P} \boldsymbol{m} \overline{\mathbf{3}} \boldsymbol{m}$ & $\mathrm{a}(\AA)$ & $\mathrm{b}(\AA)$ & $\mathrm{c}(\AA)$ & volume $\left(\AA^{3}\right)$ & density \\
\hline neutrons & 4.1765 & 4.1765 & 4.1765 & 72.853 & 6.6861 \\
$\mathrm{X}$ rays & $4.1765(2)$ & $4.1765(2)$ & $4.1765(2)$ & $72.853(4)$ & $6.6861(3)$ \\
\hline
\end{tabular}

\begin{tabular}{cccccccc}
\hline atom & site & diffraction & $\mathrm{x}$ & $\mathrm{y}$ & $\mathrm{z}$ & occupancy & $\mathrm{U}_{\text {iso }}\left(\AA^{2}\right)$ \\
\hline $\mathrm{Ba}$ & $1(\mathrm{~b})$ & neutrons & 0.5 & 0.5 & 0.5 & 1 & $0.0148(2)$ \\
& & $\mathrm{X}$ rays & 0.5 & 0.5 & 0.5 & 1 & 0.0148 \\
\hline $\mathrm{In} / \mathrm{Mo}$ & $(1 \mathrm{a})$ & neutrons & 0 & 0 & 0 & $0.75 / 0.25$ & $0.0094(2)$ \\
& & X rays & 0 & 0 & 0 & $0.75 / 0.25$ & 0.0094 \\
\hline $\mathrm{O}(1)$ & $3(\mathrm{f})$ & neutrons & 0 & 0 & 0.5 & 0.96 & $0.033(1)^{* *}$ \\
& & X rays & 0 & 0 & 0.5 & 0.96 & $0.033^{* *}$ \\
\hline
\end{tabular}

\begin{tabular}{ccccccc}
${ }^{* * *} \mathrm{U}_{\text {anharm }}$ & $\mathrm{U}_{11}$ & $\mathrm{U}_{22}$ & $\mathrm{U}_{33}$ & $\mathrm{U}_{12}$ & $\mathrm{U}_{13}$ & $\mathrm{U}_{23}$ \\
\hline $\mathrm{O}$ & $0.037(1)$ & $0.037(1)$ & $0.026(2)$ & 0 & 0 & 0 \\
\hline
\end{tabular}




\section{Table 5}

Structural model of $\mathrm{Ba}_{2} \operatorname{In}_{2-\mathrm{x}} \mathrm{Mo}_{\mathrm{x}} \mathrm{O}_{5+3 \mathrm{x} / 2}(\mathrm{x}=0.5)$ described in the $P m \overline{3} m$ space group deduced from the refinement of neutron data collected at $750^{\circ} \mathrm{C}$

\begin{tabular}{cccccl}
\hline $\boldsymbol{P} \boldsymbol{m} \overline{\mathbf{3}} \boldsymbol{m}$ & $\mathrm{a}(\AA)$ & $\mathrm{b}(\AA)$ & $\mathrm{c}(\AA)$ & volume $\left(\AA^{3}\right)$ & density \\
\hline neutrons & $4.21671(4)$ & $4.21671(4)$ & $4.21671(4)$ & $74.9763(8)$ & $6.49672(7)$ \\
\hline
\end{tabular}

\begin{tabular}{cccccccc}
\hline atom & site & diffraction & $\mathrm{x}$ & $\mathrm{y}$ & $\mathrm{z}$ & occupancy & $\mathrm{U}_{\text {iso }}\left(\AA^{2}\right)$ \\
\hline $\mathrm{Ba}$ & $1(\mathrm{~b})$ & neutrons & 0.5 & 0.5 & 0.5 & 1 & $0.0343(4)$ \\
\hline $\mathrm{In} / \mathrm{Mo}$ & $1(\mathrm{a})$ & neutrons & 0 & 0 & 0 & $0.75 / 0.25$ & $0.0244(4)$ \\
\hline $\mathrm{O}$ & $3(\mathrm{~d})$ & neutrons & 0 & 0 & 0.5 & 0.96 & $0.0559(9)^{* *}$ \\
\hline
\end{tabular}

\begin{tabular}{ccccccc}
\hline${ }^{* *} \mathrm{U}_{\text {anharm }}$ & $\mathrm{U}_{11}$ & $\mathrm{U}_{22}$ & $\mathrm{U}_{33}$ & $\mathrm{U}_{12}$ & $\mathrm{U}_{13}$ & $\mathrm{U}_{23}$ \\
\hline $\mathrm{O}$ & $0.063(1)$ & $0.063(1)$ & $0.043(1)$ & 0 & 0 & 0 \\
\hline
\end{tabular}

\section{Figure captions}

Fig. 1. Arrhenius plot of $\mathrm{Ba}_{2} \operatorname{In}_{2-\mathrm{x}} \mathrm{Mo}_{\mathrm{x}} \mathrm{O}_{5+3 \mathrm{x} / 2}$ with $\mathrm{x}=0,0.1,0.5$

Fig. 2. Description of the crystal structure of $\mathrm{Ba}_{2} \mathrm{In}_{2} \mathrm{O}_{5}$ in the a) Pcmn and b) Ibm2 space groups

Fig. 3. $\operatorname{In}(2)$ surrounding in the average structural model of $\mathrm{Ba}_{2} \mathrm{In}_{2} \mathrm{O}_{5}$ described in the Icmm space group. $\operatorname{In}(2)$ and $O(3)$ are split sites which are partially occupied. This splitting corresponds to two different configurations, one set is represented in black with full lines for bond length, the other is given in grey with dashed lines for bond length.

Fig. 4. Calculated profile compared to experimental data (neutron (a) and X-ray (b) diffraction data) of $\mathrm{Ba}_{2} \mathrm{In}_{2-\mathrm{x}} \mathrm{Mo}_{\mathrm{x}} \mathrm{O}_{5+3 \mathrm{x} / 2} \mathrm{x}=0.1$ obtained at room temperature

Fig. 5. Calculated profile compared to experimental data (neutron (a) and X-ray (b) diffraction data) of $\mathrm{Ba}_{2} \mathrm{In}_{2-\mathrm{x}} \mathrm{Mo}_{\mathrm{x}} \mathrm{O}_{5+3 \mathrm{x} / 2} \mathrm{x}=0.1$ obtained at $700^{\circ} \mathrm{C}$ 
Fig. 6. 3D plot drawing of the Joint Probability Density Function of oxygen nucleons around the indium atoms in case of $\mathrm{Ba}_{2} \mathrm{In}_{2-\mathrm{x}} \mathrm{Mo}_{\mathrm{x}} \mathrm{O}_{5+3 \mathrm{x} / 2} \mathrm{x}=0.1$ obtained at $700^{\circ} \mathrm{C}$

Fig. 7. Calculated profile compared to experimental data (neutron (a) and X-ray (b) diffraction data) of $\mathrm{Ba}_{2} \operatorname{In}_{2-\mathrm{x}} \mathrm{Mo}_{\mathrm{x}} \mathrm{O}_{5+3 \mathrm{x} / 2} \mathrm{x}=0.1$ collected at $950^{\circ} \mathrm{C}$

Fig. 8. Drawing of the Joint Probability Density Function of oxygen nucleons around the indium atoms in case of $\mathrm{Ba}_{2} \mathrm{In}_{2-\mathrm{x}} \mathrm{Mo}_{\mathrm{x}} \mathrm{O}_{5+3 \mathrm{x} / 2} \mathrm{x}=0.1$ collected at $950^{\circ} \mathrm{C}$

Fig. 9. Calculated profile compared to experimental data (neutron (a) and diffraction (b) data) of $\mathrm{Ba}_{2} \mathrm{In}_{2-\mathrm{x}} \mathrm{Mo}_{\mathrm{x}} \mathrm{O}_{5+3 \mathrm{x} / 2} \mathrm{x}=0.5$ collected at room temperature

Fig. 10. Calculated profile compared to experimental neutron data of $\mathrm{Ba}_{2} \operatorname{In}_{2-\mathrm{x}} \mathrm{Mo}_{\mathrm{x}} \mathrm{O}_{5+3 \mathrm{x} / 2} \quad \mathrm{x}=0.5$ obtained at $750^{\circ} \mathrm{C}$

Fig. 11. Drawing of the Joint Probability Density Function of oxygen nucleons around the indium atoms in case of $\mathrm{Ba}_{2} \mathrm{In}_{2-\mathrm{x}} \mathrm{Mo}_{\mathrm{x}} \mathrm{O}_{5+3 \mathrm{x} / 2} \mathrm{x}=0.5$ obtained at room temperature (a) and at $750^{\circ} \mathrm{C}(\mathrm{b})$. 


\section{Figures}

Fig. 1. Arrhenius plot of $\mathrm{Ba}_{2} \mathrm{In}_{2-\mathrm{x}} \mathrm{Mo}_{\mathrm{x}} \mathrm{O}_{5+3 \mathrm{x} / 2}$ with $\mathrm{x}=0,0.1,0.5$

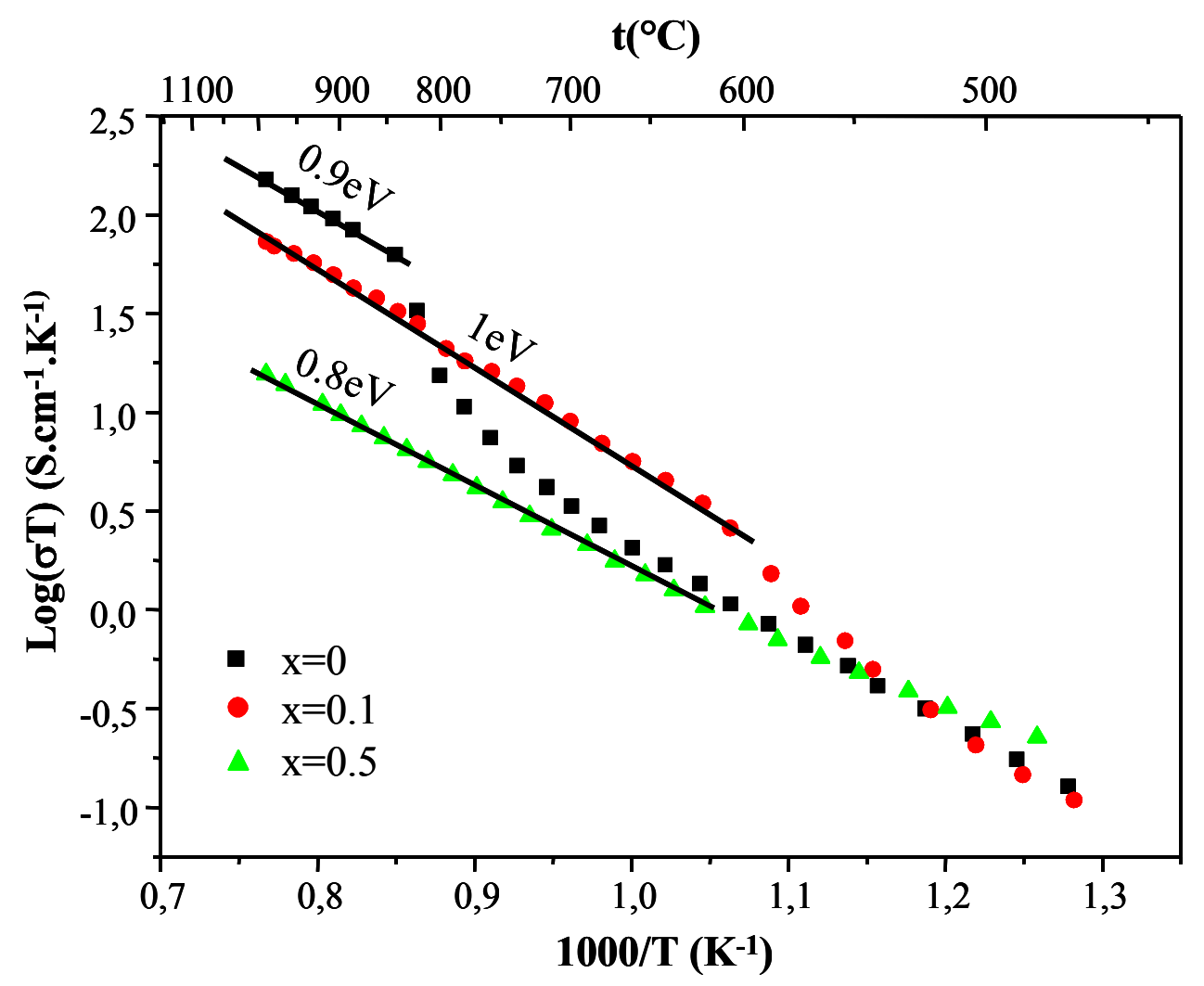

Fig. 2. Description of the crystal structure of $\mathrm{Ba}_{2} \mathrm{In}_{2} \mathrm{O}_{5}$ in the a) $P c m n$ and b) $I b m 2$ space groups

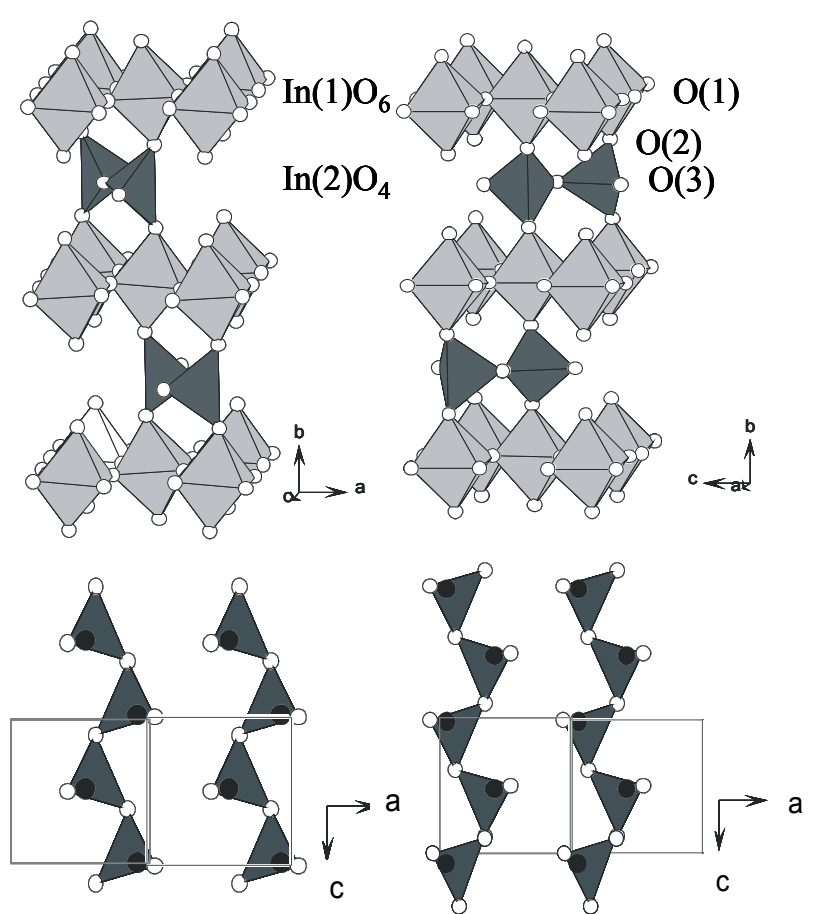

$\mathrm{y}=0.25$

a) Pcmn $\quad \mathrm{y}=0.75$

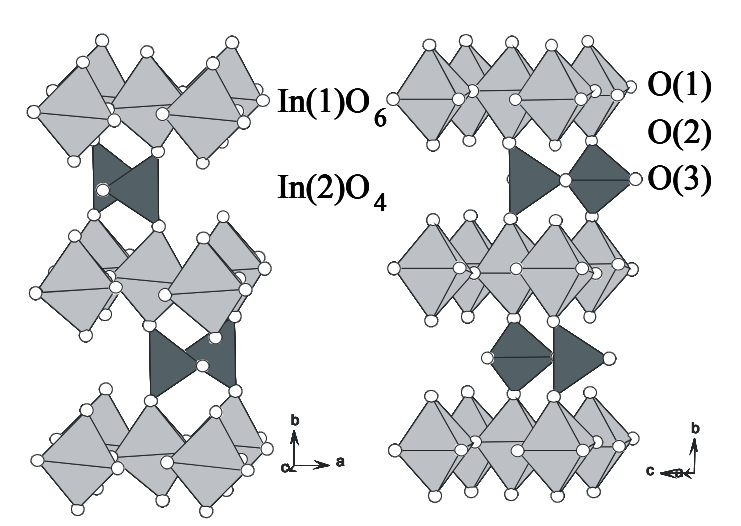

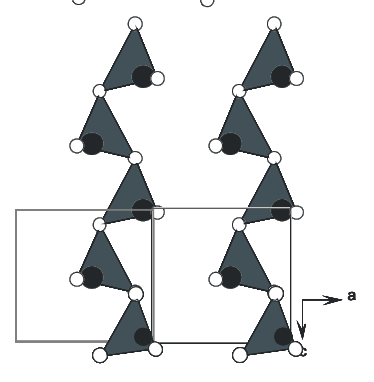

$\mathrm{y}=0.25$

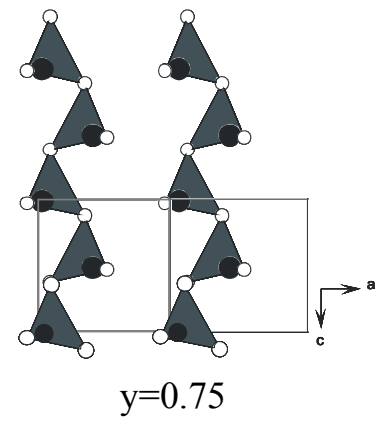

b) $\operatorname{Ibm} 2$ 
Fig. 3. In(2) surrounding in the average structural model of $\mathrm{Ba}_{2} \operatorname{In}_{2} \mathrm{O}_{5}$ described in the Icmm space group. $\operatorname{In}(2)$ and $\mathrm{O}(3)$ are split sites which are partially occupied. This splitting corresponds to two different configurations, one set is represented in black with full lines for bond length, the other is given in grey with dashed lines for bond length.

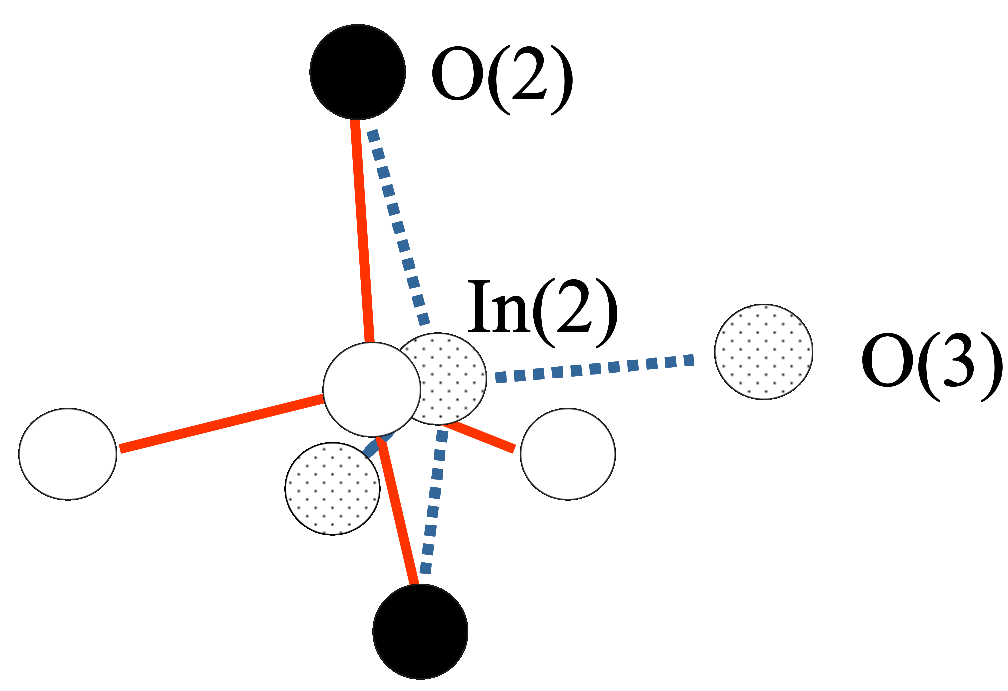


Fig. 4. Calculated profile compared to experimental data (neutron (a) and X-ray (b) diffraction data) of $\mathrm{Ba}_{2} \mathrm{In}_{2-\mathrm{x}} \mathrm{Mo}_{\mathrm{x}} \mathrm{O}_{5+3 \mathrm{x} / 2} \mathrm{x}=0.1$ collected at room temperature

(a)

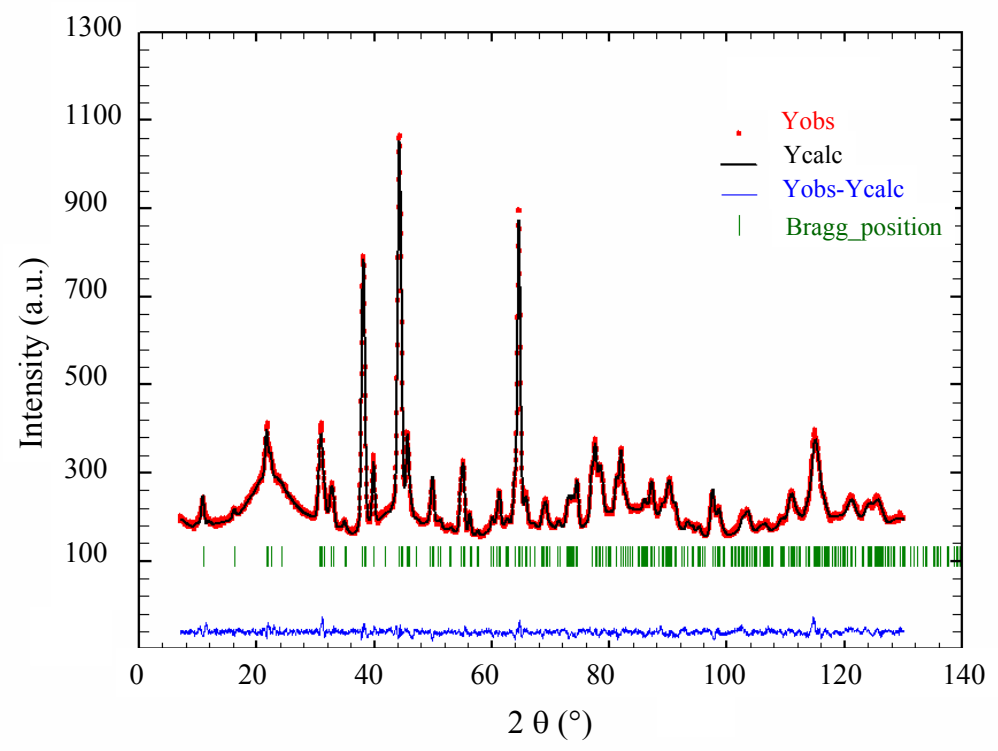

\begin{tabular}{ccccccc}
\hline $\mathrm{R}_{\text {obs }}$ & $\mathrm{R}_{\text {wobs }}$ & $\mathrm{R}_{\text {all }}$ & $\mathrm{R}_{\text {wall }}$ & $\mathrm{R}_{\mathrm{p}}$ & $\mathrm{R}_{\mathrm{wp}}$ & $\mathrm{R}_{\text {exp }}$ \\
\hline 2.94 & 2.26 & 2.95 & 2.26 & 1.86 & 2.37 & 1.59 \\
\hline
\end{tabular}

(b)

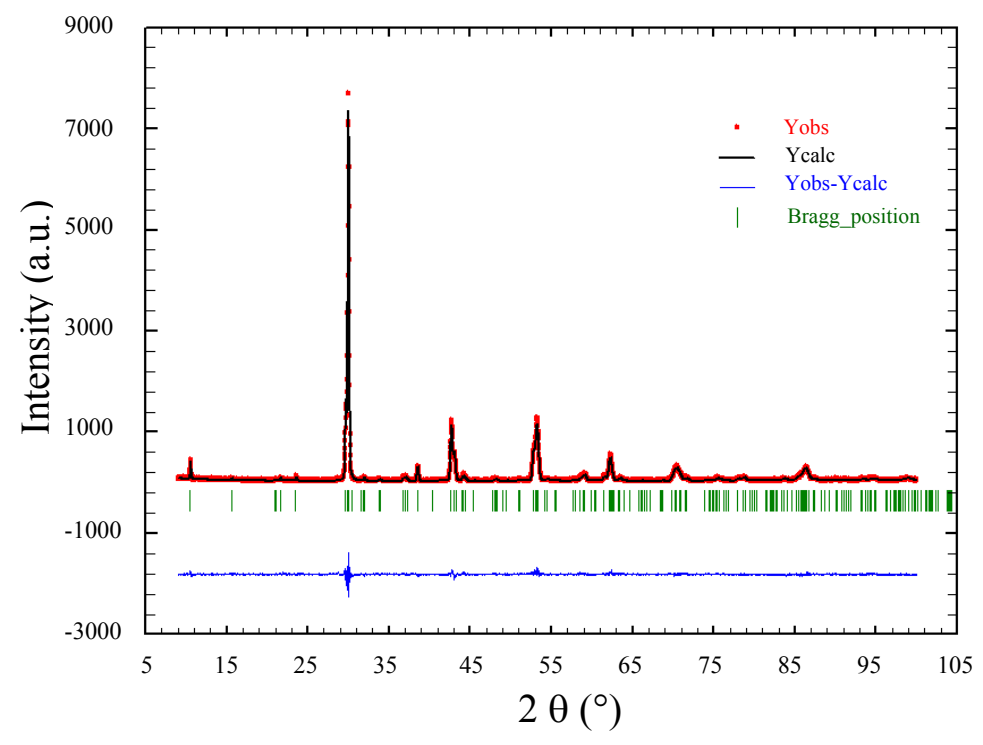


Figure 5. Calculated profile compared to experimental data (neutron (a) and X-ray (b) diffraction data) of $\mathrm{Ba}_{2} \mathrm{In}_{2-\mathrm{x}} \mathrm{Mo}_{\mathrm{x}} \mathrm{O}_{5+3 \mathrm{x} / 2} \mathrm{x}=0.1$ collected at $700^{\circ} \mathrm{C}$

(a)

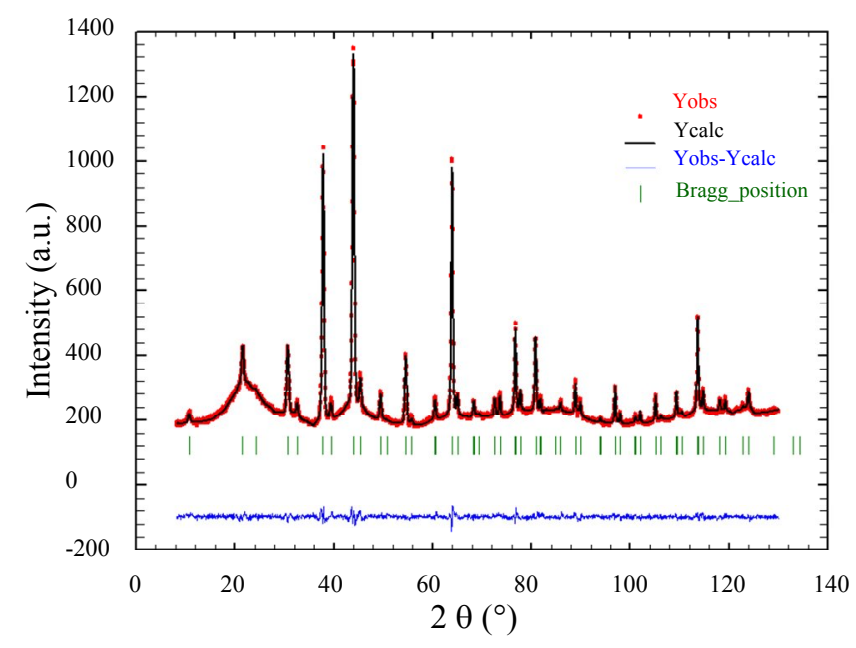

\begin{tabular}{lllllll}
\hline $\mathrm{R}_{\text {obs }}$ & $\mathrm{R}_{\text {wobs }}$ & $\mathrm{R}_{\text {all }}$ & $\mathrm{R}_{\text {wall }}$ & $\mathrm{R}_{\mathrm{p}}$ & $\mathrm{R}_{\mathrm{wp}}$ & $\mathrm{R}_{\mathrm{exp}}$ \\
\hline 2.55 & 1.39 & 2.71 & 1.40 & 1.67 & 2.12 & 1.56 \\
\hline
\end{tabular}

(b)

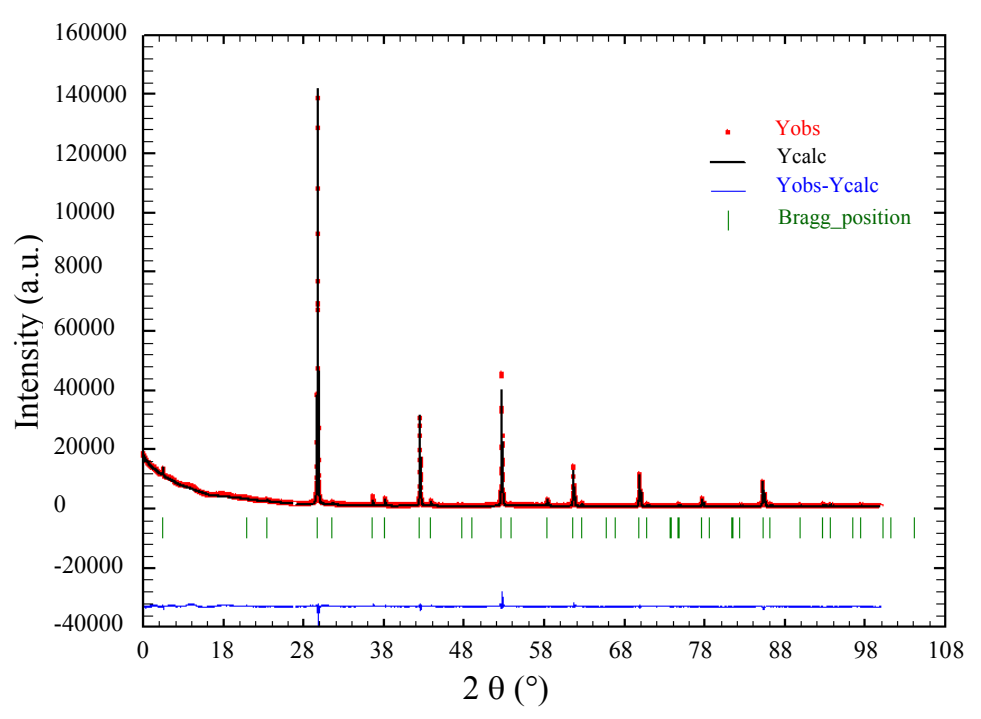

\begin{tabular}{lllllll}
\hline $\mathrm{R}_{\text {obs }}$ & $\mathrm{R}_{\text {wobs }}$ & $\mathrm{R}_{\text {all }}$ & $\mathrm{R}_{\text {wall }}$ & $\mathrm{R}_{\mathrm{p}}$ & $\mathrm{R}_{\mathrm{wp}}$ & $\mathrm{R}_{\mathrm{exp}}$ \\
\hline 6.29 & 3.16 & 7.00 & 3.17 & 4.34 & 5.99 & 2.06 \\
\hline
\end{tabular}


Fig. 6. 3D plot drawing of the Joint Probability Density Function of oxygen nucleons around the indium atoms in case of $\mathrm{Ba}_{2} \mathrm{In}_{2-\mathrm{x}} \mathrm{Mo}_{\mathrm{x}} \mathrm{O}_{5+3 \mathrm{x} / 2} \mathrm{x}=0.1$ collected at $700^{\circ} \mathrm{C}$
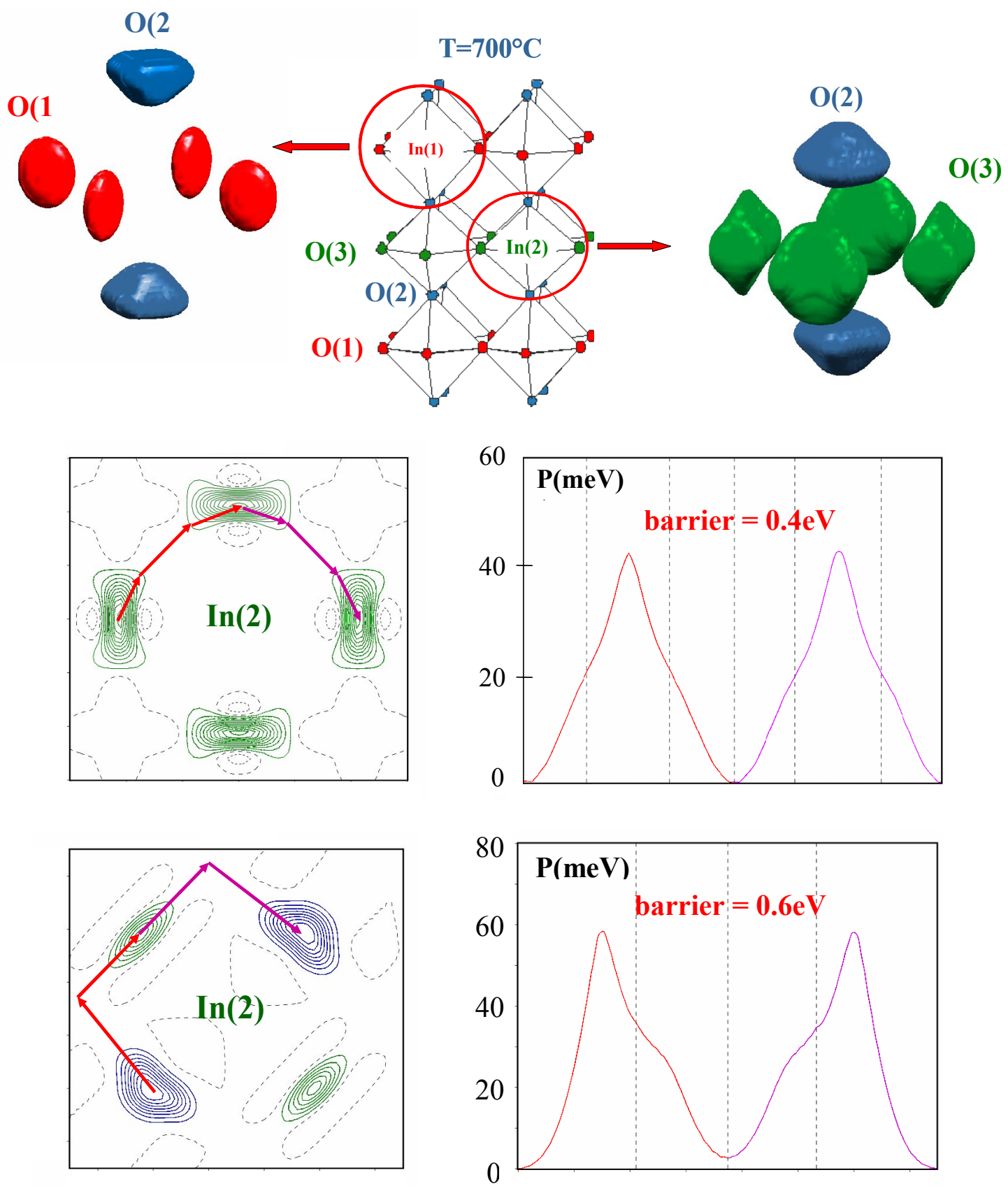

55

56

57

58

59

60

61

62 
Fig. 7. Calculated profile compared to experimental data (neutron (a) and X-ray (b) diffraction data) of $\mathrm{Ba}_{2} \mathrm{In}_{2-\mathrm{x}} \mathrm{Mo}_{\mathrm{x}} \mathrm{O}_{5+3 \mathrm{x} / 2} \mathrm{x}=0.1$ collected at $950^{\circ} \mathrm{C}$

(a)

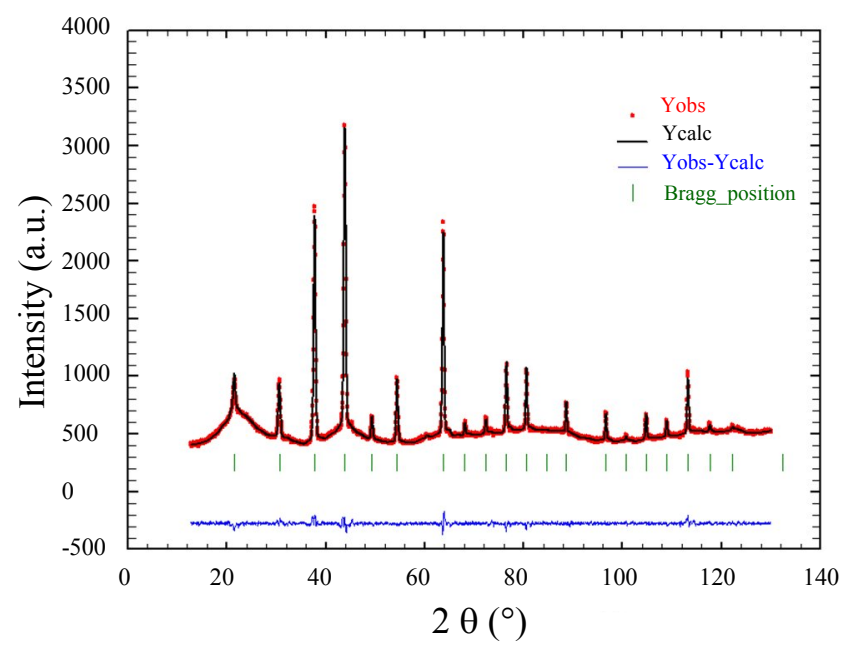

\begin{tabular}{lllllll}
\hline $\mathrm{R}_{\text {obs }}$ & $\mathrm{R}_{\text {wobs }}$ & $\mathrm{R}_{\text {all }}$ & $\mathrm{R}_{\text {wall }}$ & $\mathrm{R}_{\mathrm{p}}$ & $\mathrm{R}_{\mathrm{wp}}$ & $\mathrm{R}_{\mathrm{exp}}$ \\
\hline 1.85 & 1.68 & 2.21 & 1.69 & 1.51 & 2.00 & 1.43 \\
\hline
\end{tabular}

(b)

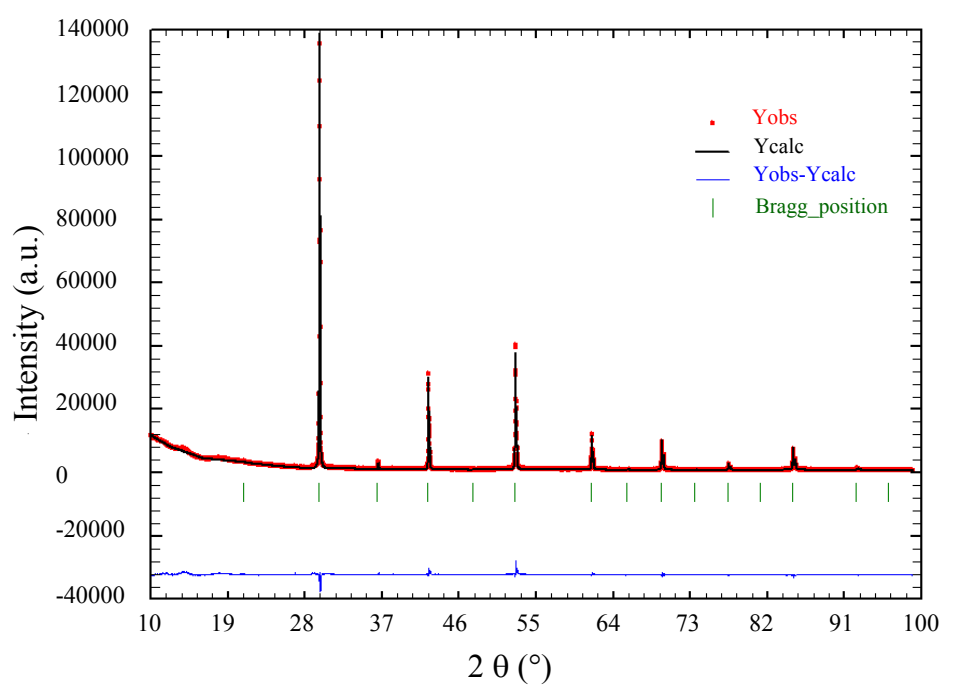

\begin{tabular}{lllllll}
\hline $\mathrm{R}_{\mathrm{obs}}$ & $\mathrm{R}_{\text {wobs }}$ & $\mathrm{R}_{\text {all }}$ & $\mathrm{R}_{\text {wall }}$ & $\mathrm{R}_{\mathrm{p}}$ & $\mathrm{R}_{\mathrm{wp}}$ & $\mathrm{R}_{\mathrm{exp}}$ \\
\hline 4.80 & 2.87 & 6.30 & 2.88 & 4.53 & 6.26 & 2.14 \\
\hline
\end{tabular}


Fig. 8. Drawing of the Joint Probability Density Function of oxygen nucleons around the indium atoms in case of $\mathrm{Ba}_{2} \mathrm{In}_{2-\mathrm{x}} \mathrm{Mo}_{\mathrm{x}} \mathrm{O}_{5+3 \mathrm{x} / 2} \mathrm{x}=0.1$ collected at $950^{\circ} \mathrm{C}$
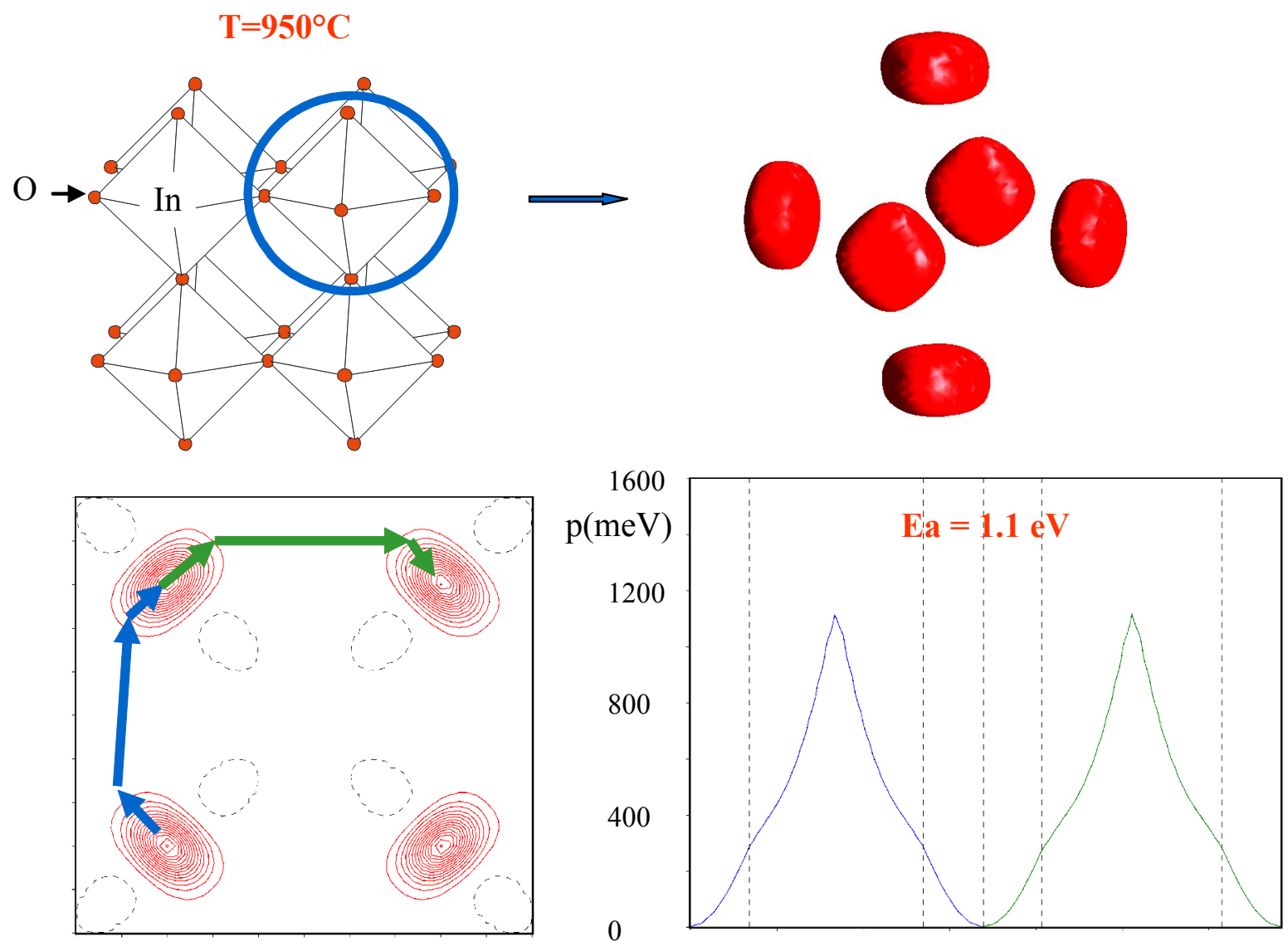
Fig. 9. Calculated profile compared to experimental data (neutron (a) and diffraction (b) data) of $\mathrm{Ba}_{2} \mathrm{In}_{2-\mathrm{x}} \mathrm{Mo}_{\mathrm{x}} \mathrm{O}_{5+3 \mathrm{x} / 2} \mathrm{x}=0.5$ collected at room temperature

(a)

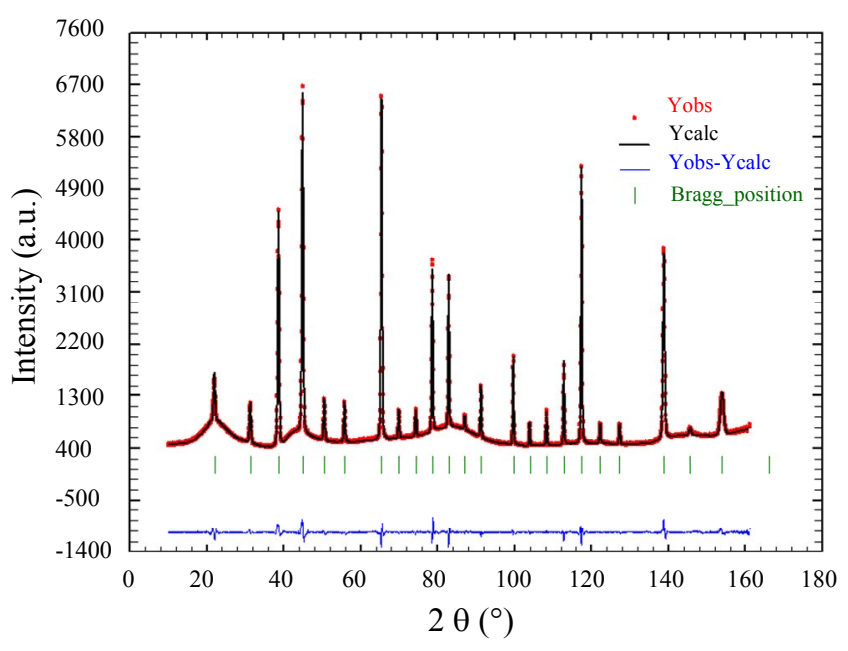

\begin{tabular}{lllllll}
\hline $\mathrm{R}_{\text {obs }}$ & $\mathrm{R}_{\mathrm{wobs}}$ & $\mathrm{R}_{\text {all }}$ & $\mathrm{R}_{\mathrm{wall}}$ & $\mathrm{R}_{\mathrm{p}}$ & $\mathrm{R}_{\mathrm{wp}}$ & $\mathrm{R}_{\mathrm{exp}}$ \\
\hline 1.10 & 1.15 & 1.10 & 1.15 & 1.70 & 2.51 & 0.92 \\
\hline
\end{tabular}

(b)

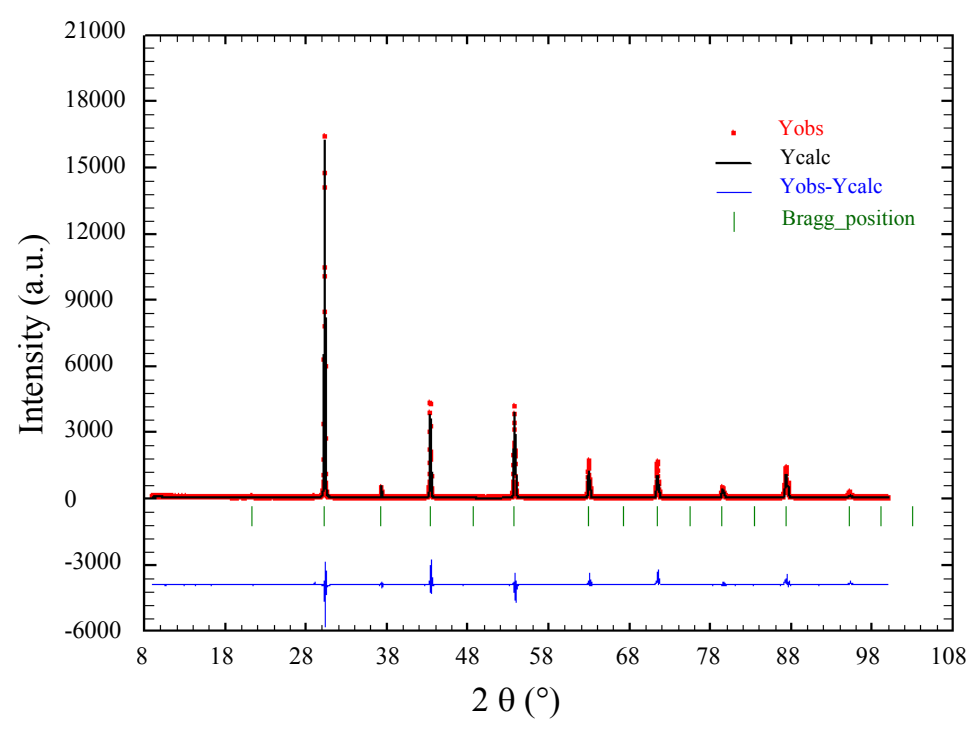

\begin{tabular}{lllllll}
\hline $\mathrm{R}_{\text {obs }}$ & $\mathrm{R}_{\text {wobs }}$ & $\mathrm{R}_{\text {all }}$ & $\mathrm{R}_{\text {wall }}$ & $\mathrm{R}_{\mathrm{p}}$ & $\mathrm{R}_{\mathrm{wp}}$ & $\mathrm{R}_{\exp }$ \\
\hline 6.72 & 5.34 & 6.85 & 5.34 & 14.28 & 18.15 & 9.95 \\
\hline
\end{tabular}


Fig. 10. Calculated profile compared to experimental neutron data of $\mathrm{Ba}_{2} \mathrm{In}_{2-\mathrm{x}} \mathrm{Mo}_{\mathrm{x}} \mathrm{O}_{5+3 \mathrm{x} / 2} \mathrm{x}=0.5$ collected at $750^{\circ} \mathrm{C}$

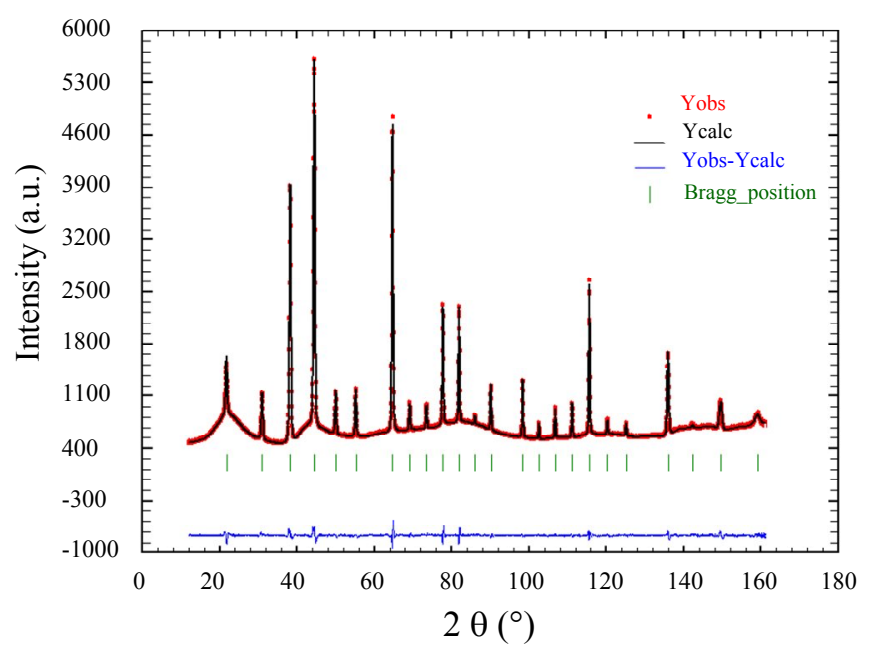

\begin{tabular}{lllllll}
\hline $\mathrm{R}_{\text {obs }}$ & $\mathrm{R}_{\text {wobs }}$ & $\mathrm{R}_{\text {all }}$ & $\mathrm{R}_{\text {wall }}$ & $\mathrm{R}_{\mathrm{p}}$ & $\mathrm{R}_{\mathrm{wp}}$ & $\mathrm{R}_{\text {exp }}$ \\
\hline 0.94 & 0.86 & 0.94 & 0.86 & 1.24 & 1.79 & 0.92 \\
\hline
\end{tabular}

Fig. 11. Drawing of the Joint Probability Density Function of oxygen nucleons around the indium atoms in case of $\mathrm{Ba}_{2} \mathrm{In}_{2-\mathrm{x}} \mathrm{Mo}_{\mathrm{x}} \mathrm{O}_{5+3 \mathrm{x} / 2} \mathrm{x}=0.5$ obtained at room temperature (a) and at $750^{\circ} \mathrm{C}(\mathrm{b})$.
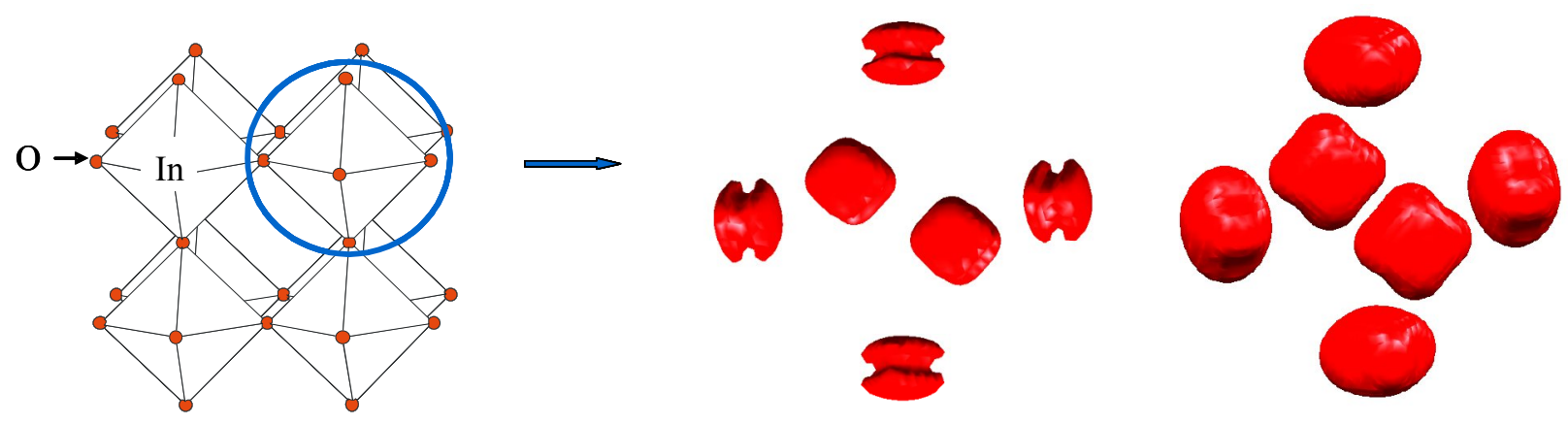

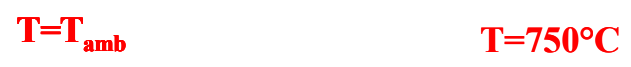

